\title{
Cattle preference for 4 wheatgrass taxa
}

\author{
THOMAS A. JONES, MICHAEL H. RALPHS, AND DALE C. NIELSON
}

Authors are research geneticist, range scientist, and entomologist, USDA-ARS, Logan, Utah 84322-6300.

\begin{abstract}
We compared the preference of cattle for 12 entries, 2 of crested wheatgrass [Agropyron desertorum (Fischer ex Link) Schultes], 5 of thickspike wheatgrass [Elymus lanceolatus (Scribner \& J.G. Smith) Gould ssp. lanceolatus], 3 of Snake River wheatgrass (proposed name $E$. lanceolatus spp. wawawaiensis), and 2 of bluebunch wheatgrass [Pseudoroegneria spicata (Pursh) A. Löve] in May 1989 and 1990 at Logan, Utah. Spaced plants were randomly arranged in 4 paddocks which were grazed once by 2 animals in late spring each year. Number of bites and number of visits were recorded for each entry in each paddock for the $\mathbf{2}$ animals individually. Cattle preferred Hycrest and Nordan crested wheatgrasses both years. Number of bites per plant for crested, thickspike, Snake River, and bluebunch wheatgrasses averaged 9.1, 4.3, 3.1, and 4.1, respectively, in 1989 and $6.7,3.3,3.5$, and 3.6, respectively, in 1990 . Number of visits was highly correlated with number of bites across entries. Grazing preference among entries was more highly correlated with biomass score and canopy height than basal area or maturity. Cattle preferred crested wheatgrass over the native wheatgrasses tested here during the spring grazing season.
\end{abstract}

Key Words: bluebunch wheatgrass, crested wheatgrass, northern wheatgrass, palatability, Snake River whentgrass, thickspike wheatgrass

Many researchers have measured differences in livestock preference among forages, but identifying agronomic, morphological, and nutritional traits that do not affect preference has been easier than identifying those that do. Marten (1969) cited several workers who found little relationship between preference and plant chemical composition. Townsend (1986) found that plant height, vigor, and maturity were unrelated to preference in cicer milkvetch (Astragalus cicer L.). Likewise, Burns et al. (1988) found little relationship between preference of Panicum spp. and laboratory indices of forage quality, canopy height, or percent stand. Gesshe and Walton (1981) cited some literature where preference was correlated with forage nutritive value, but more often preference and forage quality parameters were unrelated. Research concerning preference of cool-season grasses important in the semiarid western United States has been limited since Rogler (1944) published preference data of important native and introduced grasses of the northern Great Plains. Differences in steer preference, as measured by bite counts and percent utilization, were found among lines of a quackgrass [Elytrigia repens (L.) Beauv.] $\times$ bluebunch wheatgrass [ Pseudoroegneria spicata (Pursh) A. Löve] population (Truscott and Currie 1987). Information regarding the relationship between plant species' physical structure and their preference by livestock is minimal (O'Reagain 1989).

Our objective was to compare crested wheatgrass with its native triticeae relatives thickspike wheatgrass [Elymus lanceolatus (Scribner \& J.G. Smith) Gould ssp. lanceolatus], Snake River wheatgrass (proposed name $E$. lanceolatus ssp. wawawaiensis),

\footnotetext{
Contribution of Utah Agr. Exp. Sta., Journal Paper 4404, and USDA-ARS Forage and Range Research Laboratory and Poisonous Plant Research Laboratory. Manuscript accepted 24 Jul 1993.
}

and bluebunch wheatgrass for preference by cattle during the spring grazing season. Plant biomass, canopy height, basal area, and maturity were measured to determine if either forage availability or phenological development could explain differences.

\section{Materials and Methods}

\section{Field Design}

Plants of 12 wheatgrass entries were started from seed in the spring of 1987 and transplanted from the greenhouse to the field in August. Plants were established on 1-m centers and separated by electric fences into four $216-\mathrm{m}^{2}$ paddocks. Within each paddock were 18 blocks with 12 positions, each randomly assigned to a plant of a specific entry. Thus each of the 4 paddocks consisted of $18 \times 12$ $=216$ spaced plants surrounded by a border of 'Secar'Snake River wheatgrass outside the fence.

The plots were located on a west-facing slope on a foothill site in Logan, Utah. The soil was a Sterling gravelly loam [loamyskeletal, mixed, mesic Typic Calcixerolls (10-20\% slope)]. Transplants were irrigated in 1987 and 1988 to enhance establishment before data collection began in 1989 .

The 12 entries included released varieties and unreleased populations of crested, thickspike, Snake River, and bluebunch wheatgrasses. Entries included 'Nordan' and 'Hycrest' crested wheatgrasses; 'Elbee', 'Sodar', 'Critana', T21076 (The Dalles, Ore.) , and T-38 (Tuscarora, Nev.) thickspike wheatgrasses; K27 (Riggins, Ida.), and D38 (Jones and Nielson 1993) Snake River wheatgrasses; and the diploid 'Whitmar' and the tetraploid P7845 (Winchester, Ida.) bluebunch wheatgrasses.

\section{Animal Data Collection and Analysis}

Relative preference of entries was determined by grazing two 1-year-old Hereford heifers in each paddock once each year. Grazing began between 0830 and 1000 and lasted until grazing slowed or animals began to graze nonselectively ( 37 to $65 \mathrm{~min}$ ). Grazing was considered to be nonselective when the animals began grazing adjacent plants rather than searching for more preferred plants. Several days before the test began the animals were held on an adjacent pasture of crested wheatgrass and Russian wildrye [ $P$ sathyrostachys juncea (Fischer) Nevski] to precondition them to fresh grass.

The 4 paddocks were grazed consecutively on $15,16,17$, and 18 May 1989 by the pair of heifers. Observers for each animal recorded the number of bites taken from each plant. If the animal later returned to the same plant, the number of bites was recorded separately as a second visit. To calculate the number of bites per plant, the total number of bites from a particular entry by a single animal was divided by the number of extant plants of that entry (maximum of 18). To calculate the number of visits per plant, the number of discontinuous times an animal grazed an entry was divided by the number of extant plants. Bites per visit was calculated as number of bites divided by number of visits. Plants were clipped to $100 \mathrm{~mm}$ in late June to eliminate differences between grazed and ungrazed plants the following year. The above proce- 
dure was repeated in 1990 with 2 different animals on $1,2,3$, and 4 May.

One hundred ninety-two observations ( 2 animals $\times 4$ paddocks $\times 2$ years $\times 12$ entries) were available for analysis of variance. Each animal per paddock was considered an independent replication. Years and replications (nested within years) were considered random while taxa and entries within taxa were considered fixed. Entries were arranged in the field in a randomized complete block design. Differences among the 4 taxa ( $3 \mathrm{df}$ ) and entries within taxa $(8 \mathrm{~d})$ were tested with the entry $\times$ year mean square, while their interactions with year were tested with the residual mean square. $A$ single degree-of-freedom contrast "crested wheatgrass vs. other taxa' was partitioned from the taxon sum of squares. Entry means were separated by the Bayes L.S.D. with k ratio $=100$ (Smith 1978).

\section{Plant Data Collection and Analysis}

Immediately before grazing both years, we measured aboveground biomass score, canopy height, and basal area of individual plants in each paddock. The biomass scores were the average ratings of 2 observers, based on a scale of $1=$ least to $9=$ most vigorous. Basal area, the area occupied by a plant at ground level, was estimated by $\pi$ multiplied by the product of the greatest radius (half the longest distance from edge to edge) and its greatest perpendicular radius (half the length of the longest perpendicular from edge to edge of the greatest radius). Basal area especially distinguished the rhizomatous thickspike wheatgrass from the other taxa which were bunchgrasses. Ocular estimates of canopy height (height of the average mature tiller) were made by placing a meterstick in the center of the plant canopy. Maturity was measured differently in 1990 from 1989. In 1989, average date of first head emergence was calculated from an adjacent nursery of ungrazed spaced plants outside the paddock. A separate ungrazed nursery was necessary because head emergence continued beyond the time of grazing. Because correlation with animal data was of greatest interest, we changed the procedure in 1990. Maturity of plants within the paddock was scored immediately before grazing based on a scale of $1=$ early head to $5=$ vegetative. The 1989 procedure provided a better measure of the relative maturity of the 12 entries, but the data collected in 1990 at the time of grazing was more appropriate for correlation with the animal data. Differences between entries for plant traits were tested with the paddock $X$ entry interaction in 1989 and 1990 . Entry means were separated using the Bayes L.S.D. $(\mathrm{k}$ ratio $=100)$. Data are presented as least-squares means. Correlations between the 4 plant traits, number of bites, and number of visits were calculated among the 12 entry means in 1989 and 1990.

\section{Results and Discussion}

Number of bites in 1989 covered an 11-fold range from 0.9 bites/plant for T-38 thickspike wheatgrass to 9.8 bites/plant for Hycrest crested wheatgrass $(P<0.01$; Table 1$)$. In contrast, in 1990 the entries encompassed only a 6 -fold range $(P<0.01)$. With the exception of K27 Snake River wheatgrass, number of bites in 1990 was similar to 1989 for lower-ranking entries but lower than 1989 for higher-ranking entries. The tax on $X$ year interaction was significant $(P<0.05)$ because the number of bites of thickspike and crested wheatgrass declined from 1989 to 1990 while the number for bluebunch and Snake River wheatgrasses was similar for both years. Because of this interaction, data for the 2 years are presented separately. The 8 -df entry within taxon $\times$ year interaction was nonsignificant $(P>0.10)$.

Number of bites for crested, thickspike, Snake River, and bluebunch wheatgrasses averaged $9.2,4.3,3.1$, and 4.1 , respectively, in 1989 and 6.7, 3.3, 3.5, and 3.6, respectively, in 1990. Hycrest and Nordan crested wheatgrasses were the highest ranking entries both
Table 1. Bites per animal of 12 crested (CWG), thickspike (TSWG), Snake River (SRWG), and bluebunch (BBWG) wheatgrass entries in 1989 ( $\mathrm{n}=$ 8) and $1990(n=8)^{4}$.

\begin{tabular}{|c|c|c|c|}
\hline \multicolumn{2}{|l|}{1989} & \multicolumn{2}{|l|}{1990} \\
\hline Entry & Bites & Entry & Bites \\
\hline $\begin{array}{l}\text { Hycrest CWG } \\
\text { Nordan CWG } \\
\text { T21076 TSWG } \\
\text { Elbee TSWG } \\
\text { P7845 BBWG } \\
\text { Critana TSWG } \\
\text { K27 SRWG } \\
\text { Sodar TSWG } \\
\text { Secar SRWG } \\
\text { Whitmar BBWG } \\
\text { D38 SRWG } \\
\text { T-38 TSWG }\end{array}$ & $\begin{array}{c}- \text { no. } / \text { plant- } \\
9.8 \mathrm{a}^{2} \\
8.3 \mathrm{a} \\
6.1 \mathrm{~b} \\
6.0 \mathrm{~b} \\
5.5 \mathrm{bc} \\
5.0 \mathrm{bcd} \\
4.1 \mathrm{bcde} \\
3.7 \mathrm{cde} \\
3.2 \mathrm{de} \\
2.7 \mathrm{ef} \\
2.1 \mathrm{ef} \\
0.9 \mathrm{f}\end{array}$ & $\begin{array}{l}\text { Hycrest CWG } \\
\text { Nordan CWG } \\
\text { K27 SRWG } \\
\text { T21076 TSWG } \\
\text { P7845 BBWG } \\
\text { Critana TSWG } \\
\text { Elbee TSWG } \\
\text { Secar SRWG } \\
\text { Whitmar BBWG } \\
\text { Sodar TSWG } \\
\text { D38 SRWG } \\
\text { T-38 TSWG }\end{array}$ & $\begin{array}{c}- \text { no. } / \text { plant- } \\
6.9 \mathrm{a} \\
6.5 \mathrm{a} \\
5.7 \mathrm{ab} \\
4.9 \mathrm{abc} \\
4.3 \mathrm{bcd} \\
4.1 \mathrm{bcd} \\
4.0 \mathrm{bcd} \\
3.0 \mathrm{cde} \\
2.9 \mathrm{de} \\
2.5 \mathrm{de} \\
1.9 \mathrm{e} \\
1.1 \mathrm{e}\end{array}$ \\
\hline L.S.D. & 2.1 & & 2.0 \\
\hline
\end{tabular}

Taxon $\times$ year interaction significant $(P<0.05)$. Entry within tax on $\times$ year interaction not significant $(P>0,10)$.

2Values within a column not followed by the same letter are significantly different according to the Bayes L.S.D. (k ratio $=100$ ).

years, though their superiority was greater in 1989 than 1990 . The contrast 'crested wheatgrass vs other taxa' was significant $(P<0.01)$ both years and accounted for 94 and $95 \%$ of the variation between taxa in 1989 and 1990, respectively. D38 Snake River and T-38 thickspike wheatgrasses had the fewest number of bites both years.

Number of visits was highly correlated with number of bites across entries, $r^{2}=0.96$ in 1989 and 0.86 in 1990 . However, unlike number of bites, there were no significant interactions between taxon or entry within tax on with year $(P>0.10)$, so results for the 2 years were combined (Table 2). Like number of bites, differences

Table 2. Visits per animal and bites per visit of 12 crested (CWG), thickspike (TSWG), Snake River (SRWG), and bluebunch (BBWG) wheatgrass entries averaged over $1989(n=8)$ and $1990(n=8)^{1}$.

\begin{tabular}{|c|c|c|c|}
\hline \multicolumn{2}{|l|}{1989} & \multicolumn{2}{|l|}{1990} \\
\hline Entry & Bites & Entry & Bites \\
\hline & -no./plant- & & -no./plant- \\
\hline Nordan CWG & $0.89 \mathrm{a}^{2}$ & Elbee TSWG & $10.2 \mathrm{a}$ \\
\hline Hycrest CWG & $0.89 \mathrm{a}$ & Hycrest CWG & $9.9 \mathrm{ab}$ \\
\hline K27 SRWG & $0.67 \mathrm{~b}$ & T21076 TSWG & $9.8 \mathrm{ab}$ \\
\hline T21076 TSWG & $0.65 \mathrm{bc}$ & Sodar TSWG & $8.6 \mathrm{abc}$ \\
\hline Critana TSWG & $0.63 \mathrm{bc}$ & P7845 BBWG & $8.5 \mathrm{abc}$ \\
\hline P7845 BBWG & $0.62 b c$ & Nordan CWG & $8.4 \mathrm{abc}$ \\
\hline Secar SRWG & $0.52 \mathrm{~cd}$ & Critana TSWG & $7.8 \mathrm{bc}$ \\
\hline Elbee TSWG & 0.52 cde & K27 SRWG & $7.2 \mathrm{c}$ \\
\hline Whitmar BBWG & $0.44 \mathrm{de}$ & Secar SRWG & $6.6 \mathrm{~cd}$ \\
\hline D38 SRWG & $0.42 \mathrm{def}$ & Whitmar BBWG & $6.6 \mathrm{~cd}$ \\
\hline Sodar TSWG & 0.37 ef & D38 SRWG & $4.9 \mathrm{de}$ \\
\hline T-38 TSWG & $0.28 \mathrm{f}$ & T-38 TSWG & $3.6 \mathrm{e}$ \\
\hline L.S.D. & 0.14 & & 2.2 \\
\hline
\end{tabular}

1Taxon $\times$ year and entry within $\operatorname{tax}$ on $X$ year interaction not significant $(P>0.10)$ for visits and bites per visit.

2Values within a column not followed by the same letter are significantly different according to the Bayes L.S.D. $(k$ ratio $=100$ ).

among entries for number of visits was sighificant $(P<0.01)$ and greatest for Nordan and Hycrest crested wheatgrasses and lowest for T-38 thickspike wheatgrass. The contrast 'crested wheatgrass vs other taxa' was significant $(P<0.01)$ and accounted for $93 \%$ of the variation between taxa.

The entry $\times$ year interaction was also nonsignificant $(P>0.10)$ for bites/visit and data were combined across years. Entries were 
Table 3. Biomass score, canopy height, basal area, and May heading date least-squares means of 12 crested (CWG), thickspike (TSWG), Snake River (SRWG), and bluebunch (BBWG) wheatgrass entries in 1989.

\begin{tabular}{lllcc}
\hline \hline Entry & $\begin{array}{l}\text { Biomass } \\
\text { score }\end{array}$ & $\begin{array}{l}\text { Canopy } \\
\text { height }\end{array}$ & $\begin{array}{c}\text { Basal } \\
\text { area }^{2}\end{array}$ & $\begin{array}{c}\text { May } \\
\text { heading date }\end{array}$ \\
\hline Hycrest CWG & $5.6 \mathrm{a}^{3}$ & $\begin{array}{c}-\mathrm{mm}- \\
356 \mathrm{~b}\end{array}$ & $\begin{array}{c}-\mathrm{cm}^{2}- \\
295 \mathrm{e}\end{array}$ & $23.1 \mathrm{bc}$ \\
Nordan CWG & $4.6 \mathrm{~b}$ & $308 \mathrm{~cd}$ & $237 \mathrm{ef}$ & $19.9 \mathrm{de}$ \\
Critana TSWG & $4.7 \mathrm{~b}$ & $315 \mathrm{c}$ & $623 \mathrm{c}$ & $21.0 \mathrm{~cd}$ \\
Elbee TSWG & $4.1 \mathrm{~cd}$ & $285 \mathrm{de}$ & $607 \mathrm{~cd}$ & $19.7 \mathrm{de}$ \\
Sodar TSWG & $3.9 \mathrm{de}$ & $284 \mathrm{de}$ & $474 \mathrm{~d}$ & $19.2 \mathrm{de}$ \\
T21076 TSWG & $5.9 \mathrm{a}$ & $389 \mathrm{a}$ & $1426 \mathrm{a}$ & $25.2 \mathrm{ab}$ \\
T-38 TSWG & $3.4 \mathrm{ef}$ & $253 \mathrm{f}$ & $921 \mathrm{~b}$ & $26.2 \mathrm{a}$ \\
Secar SRWG & $3.2 \mathrm{f}$ & $312 \mathrm{~cd}$ & $97 \mathrm{f}$ & $20.9 \mathrm{~cd}$ \\
D38 SRWG & $2.5 \mathrm{~g}$ & $246 \mathrm{f}$ & $116 \mathrm{f}$ & $25.1 \mathrm{ab}$ \\
K27 SRWG & $4.4 \mathrm{bc}$ & $397 \mathrm{a}$ & $125 \mathrm{f}$ & $19.5 \mathrm{de}$ \\
Whitmar BBWG $2.7 \mathrm{~g}$ & $267 \mathrm{ef}$ & $120 \mathrm{f}$ & $19.2 \mathrm{de}$ \\
P7845 BBWG & $4.3 \mathrm{bcd}$ & $372 \mathrm{ab}$ & $199 \mathrm{ef}$ & $17.6 \mathrm{c}$ \\
L.S.D. & 0.5 & 29 & 148 & 2.6 \\
\hline
\end{tabular}

'Biomass scored from $1=$ least to $9=$ most.

2Basal area estimated as $\pi \times$ product of the greatest radius and its greatest perpendicular radius.

${ }^{3}$ Values within a column not followed by the same letter are significantly differen according to the Bayes L.S.D. (k ratio $=100)$.

significantly different $(P<0.01)$ for this trait. Bites/visit was highest for Elbee thickspike wheatgrass; however Hycrest and Nordan crested, T21076 and Sodar thickspike, and P7845 bluebunch wheatgrasses were statistically similar $(k$ ratio $=100)$ to Elbee. Judged by this parameter, D38 Snake River and T-38 thickspike wheatgrasses were again least preferred.

T21076 thickspike wheatgrass scored highest for biomass both years but was not significantly different $(k$ ratio $=100)$ from $\mathrm{Hy}$ crest crested wheatgrass in 1989 (Tables 3,4 ). Whitmar bluebunch

Table 4. Biomass score, canopy height, basal area, and maturity score least-squares means of 12 crested (CWG), thickspike (TSWG), Snake River (SRWG), and bluebunch (BBWG) wheatgrass entries in 1990.

\begin{tabular}{llccc}
\hline \hline Entry & $\begin{array}{l}\text { Biomass } \\
\text { score }\end{array}$ & $\begin{array}{l}\text { Canopy } \\
\text { height }\end{array}$ & $\begin{array}{l}\text { Basal } \\
\text { area }^{2}\end{array}$ & $\begin{array}{c}\text { Maturity } \\
\text { score }\end{array}$ \\
\hline Hycrest CWG & $4.7 \mathrm{~cd}^{4}$ & $\begin{array}{c}-\mathrm{mm}- \\
278 \mathrm{~cd}\end{array}$ & $\begin{array}{c}-\mathrm{cm}^{2}- \\
326 \mathrm{e}\end{array}$ & $4.5 \mathrm{ef}$ \\
Nordan CWG & $4.0 \mathrm{e}$ & $240 \mathrm{e}$ & $254 \mathrm{e}$ & $4.6 \mathrm{f}$ \\
Critana TSWG & $5.1 \mathrm{bc}$ & $266 \mathrm{~d}$ & $1076 \mathrm{c}$ & $4.6 \mathrm{f}$ \\
Elbee TSWG & $4.5 \mathrm{de}$ & $237 \mathrm{ef}$ & $1070 \mathrm{c}$ & $4.6 \mathrm{f}$ \\
Sodar TSWG & $4.0 \mathrm{e}$ & $230 \mathrm{ef}$ & $795 \mathrm{~d}$ & $4.6 \mathrm{f}$ \\
I21076 TSWG & $6.4 \mathrm{a}$ & $314 \mathrm{ab}$ & $1985 \mathrm{a}$ & $4.5 \mathrm{f}$ \\
T-38 TSWG & $4.0 \mathrm{e}$ & $214 \mathrm{f}$ & $1702 \mathrm{~b}$ & $4.9 \mathrm{~g}$ \\
Secar SRWG & $4.3 \mathrm{de}$ & $284 \mathrm{~cd}$ & $235 \mathrm{e}$ & $3.6 \mathrm{~b}$ \\
D38 SRWG & $2.8 \mathrm{f}$ & $215 \mathrm{f}$ & $184 \mathrm{e}$ & $4.3 \mathrm{de}$ \\
K27 SRWG & $5.4 \mathrm{~b}$ & $327 \mathrm{a}$ & $274 \mathrm{e}$ & $3.4 \mathrm{a}$ \\
Whitmar BBWG & $3.2 \mathrm{f}$ & $229 \mathrm{ef}$ & $184 \mathrm{e}$ & $4.1 \mathrm{~cd}$ \\
P7845 BBWG & $4.5 \mathrm{de}$ & $296 \mathrm{bd}$ & $324 \mathrm{e}$ & $3.9 \mathrm{c}$ \\
L.S.D. & 0.5 & 23 & 216 & 0.2 \\
\hline
\end{tabular}

1 Biomass scored from $1=$ least to $9=$ most.

${ }_{2}$ Basal area estimated as $\pi \times$ product of the greatest radius and its greatest perpendicular radius.

${ }^{3}$ Maturity score: 1 = early head, 2 = late boot, 3 = boot, 4 = early boot, 5 = vegetative.

"Values within a column not followed by the same letter are significantly different according to the Bayes L.S.D. $(k$ ratio $=100)$.

and D38 Snake River wheatgrasses scored lowest for biomass both years. K27 Snake River and T21076 thickspike wheatgrasses were the 2 tallest entries, closely followed by P7845. Whitmar bluebunch, D38 Snake River, and T-38, Sodar, and Elbee thickspike wheatgrasses were shortest. Of the 4 grass taxa included in the study, only thickspike wheatgrass was rhizomatous; its basal area was far greater than the others' (Tables 3,4 ). T21076 was the most rhizomatous entry, followed by T-38. Elbee, Critana, and Sodar were intermediate between these thickspike wheatgrass entries and the bunchgrasses. Entries of Snake River wheatgrass tended to mature earlier than crested and thickspike wheatgrasses both years. Coefficients of determination $\left(r^{2}\right)$ between years were 0.70 $(P<0.01)$ for biomass score, $0.92(P<0.01)$ for canopy height, 0.95 $(P<0.01)$ for basal area, and $0.20(P>0.10)$ for maturity.

Correlations between the 4 plant traits and number of bites were similar to correlations with number of visits (Table 5), both in 1989

Table 5. Correlation coefficients between number of bites, number of visits, biomass score, canopy height, basal area, and maturity (1989 May heading date, 1990 maturity score). 1989 data below the diagonal and 1990 data above the diagonal.

\begin{tabular}{|c|c|c|c|c|c|c|}
\hline & $\begin{array}{c}\text { Number } \\
\text { of } \\
\text { bites }\end{array}$ & $\begin{array}{l}\text { Number } \\
\text { of } \\
\text { visits }\end{array}$ & $\begin{array}{l}\text { Biomass } \\
\text { score }\end{array}$ & $\begin{array}{c}\text { Canopy } \\
\text { height }\end{array}$ & $\begin{array}{r}\text { Basal } \\
\text { area }\end{array}$ & $\begin{array}{l}\text { Maturity } \\
\text { score }\end{array}$ \\
\hline $\begin{array}{l}\text { Number } \\
\text { of bites }\end{array}$ & & $0.93^{* *}$ & $0.54^{+}$ & $0.60^{*}$ & -0.21 & -0.15 \\
\hline $\begin{array}{l}\text { Number } \\
\text { of visits }\end{array}$ & $0.98 * *$ & & 0.42 & $0.58 *$ & -0.32 & -0.25 \\
\hline $\begin{array}{l}\text { Biomass } \\
\text { score }\end{array}$ & $0.79^{* *}$ & $0.78^{* *}$ & & $0.81 * *$ & $0.53^{+}$ & -0.08 \\
\hline $\begin{array}{l}\text { Canopy } \\
\text { height } \\
\text { Basal }\end{array}$ & $0.54^{*}$ & $0.59 *$ & $0.75^{* *}$ & & 0.01 & $-0.60^{*}$ \\
\hline $\begin{array}{l}\text { Marea } \\
\text { May } \\
\text { heading } \\
\text { date }\end{array}$ & -0.20 & -0.04 & $0.52^{+}$ & -0.21 & 0.50 & $0.64 *$ \\
\hline
\end{tabular}

+****Correlation coefficient significant at $P<0.10,0.05$, and 0.01 , respectively.

and 1990 . In 1989 bites and visits were primarily correlated with biomass and secondarily correlated with canopy height, while in 1990 this pattern was reversed. Biomass score and canopy height were highly correlated $(P<0.01)$ both years. Numbers of bites and visits were not correlated with basal area or maturity $(P>0.10)$. At the phenological stage that these plants were grazed, biomass and height were more important determinants of animal preference than were basal area or maturity. Ganskopp and Rose (1992) found differences in frequency and level of utilization between crested wheatgrass plants distributed among 10 basal area classes. Intermediate-sized plants were most likely to be grazed. We suspect we did not see such a relationship because 4 different taxa, 3 caespitose and 1 rhizomatous, were included in our study. While immaturity is generally associated with increased preference, with the inclusion of various taxa other factors were apparently more significant than maturity alone.

Among plant traits, rhizomatous growth habit (high basal area) was correlated with biomass $(P<0.10)$ both years and with late maturity in $1990(P<0.10)$, but not with canopy height either year $(P>0.10)$. Maturity as measured by May 1989 heading data was not correlated $(P>0.10)$ with other plant traits. But, as noted above, earliness (low maturity score) was correlated $(P<0.05)$ with height and caespitose growth habit (low basal area) in 1990.

The positive correlations of bites and visits with biomass and height (Table 5) indicated that forage availability was an important factor affecting animal preference. Development of higher-yielding crested wheatgrass varieties might further improve grazing preference. O'Reagain (1984) reported that preference to cattle of 9 indigenous South African grasses was positively correlated with leaf table height and tuft diameter. He argued that leaf accessibility is an important determinant of cattle preference.

We conclude that cattle, when offered a choice, prefer crested wheatgrass to its native relatives thickspike wheatgrass, Snake 
River wheatgrass, or bluebunch wheatgrass during the spring grazing season when forage is typically most plentiful. Shewmaker et al. (1989) also found sheep preferred Nordan crested wheatgrass over bluebunch wheatgrass. Crested wheatgrass' high palatability, productivity, and grazing tolerance suggest its continued use for grazing cattle in the spring in regions where it is adapted.

\section{Literature Cited}

Burns, J.C., D.H. Timothy, R.D. Mochrie, and D.S. Fisher. 1988. Relative grazing preference of Panicum germplasm from three taxa. Agron. J. 80:574-580.

Ganskopp, David, and Jeff Rose. 1992. Bunchgrass basal area affects selection of plants by cattle. J. Range Manage. 45:538-541.

Gesshe, R.H., and P.D. Walton. 1981. Grazing animal preferences for cultivated forages in Canada. J. Range Manage. 34:42-44.

Jones, T.A., and D.C. Nielson. 1993. Spring-clipping response in Snake River and thickspike wheatgrasses. Agron. J. 85:94-97.
Marten, G.C. 1969. Measurement and significance of forage palatability. Proc. Nat. Conf. Forage Quality Evaluation and Utilization, Lincoln, Neb. 3-4 Sep. 1969. Nebraska Center for Continuing Education, Lincoln.

O'Reagain, P.J., and M.T. Mentis. 1989. The effect of plant structure on the acceptability of different grass species to cattle. J. Grassl. Soc. South Africa 6:163-170.

Rogler, G.A. 1944. Relative palatabilities of grasses under cultivation on the northern Great Plains. J. Amer. Soc. Agron. 36:487-496.

Shewmaker, Glenn E., H.F. Mayland, R.C. Rosenau, and K.H. Asay. 1989. Silicon in C-3 grasses: effects on forage quality and sheep preference. J. Range Manage. 42:122-127.

Smith, C.W. 1978. Bayes least significant difference: a review and comparison. Agron. J. 70:123-127.

Townsend, C.E. 1986. Evaluation of polycross progenies of cicer milkvetch for palatability by sheep. Crop Sci. 26:377-380.

Truscott, Doreen R., and Pat O. Currie. 1987. Factors affecting dietary preferences for genotypes of a hybrid wheatgrass. J. Range Manage. 40:509 513.

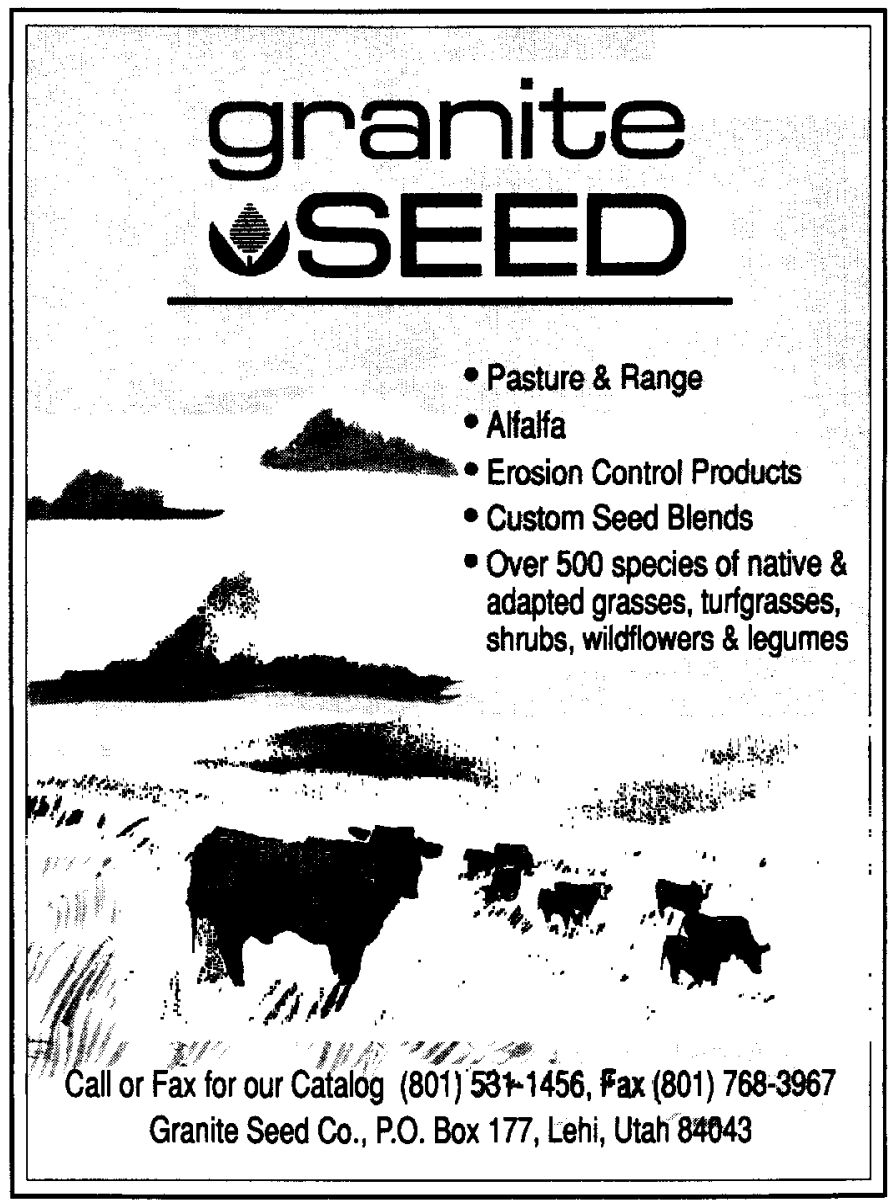

